\title{
Influence of plasminogen activator inhibitor type 1 on choroidal neovascularization
}

\author{
VINCENT LAMBERT,*,1 CARINE MUNAUT,* AGNÈS NOËL,* FRANCIS FRANKENNE,* \\ KHALID BAJOU, $*$ ROBERT GERARD ${ }^{\dagger}{ }^{\dagger}$ PETER CARMELIET, ${ }^{\dagger}$ MARIE PAULE DEFRESNE, ${ }^{\ddagger}$ \\ JEAN-MICHEL FOIDART,* AND JEAN-MARIE RAKIC ${ }^{\S}$ \\ *Laboratory of Tumor and Development Biology, University of Liège, B-4000 Liège, Belgium; \\ ${ }^{\dagger}$ Center for Transgene Technology and Gene Therapy, Flanders Interuniversity Institute for \\ Biotechnology, Campus Gasthuisberg, University of Leuven, Belgium; ${ }^{\ddagger}$ Laboratory of Cytology and \\ Histolgy, University of Liège, B-4000 Liège, Belgium; and ${ }^{\$}$ Department of Ophthalmology, University \\ Hospital, Sart-Tilman, B-4000 Liège, Belgium
}

\begin{abstract}
High levels of the plasminogen activators, but also their inhibitor, plasminogen activator inhibitor 1 (PAI-1), have been documented in neovascularization of severe ocular pathologies such as diabetic retinopathy or age-related macular degeneration (AMD). AMD is the primary cause of irreversible photoreceptors loss, and current therapies are limited. PAI-1 has recently been shown to be essential for tumoral angiogenesis. We report here that deficient PAI-1 expression in mice prevented the development of subretinal choroidal angiogenesis induced by laser photocoagulation. When systemic and local PAI-1 expression was achieved by intravenous injection of a replication-defective adenoviral vector expressing human PAI-1 cDNA, the wild-type pattern of choroidal angiogenesis was restored. These observations demonstrate the proangiogenic activity of PAI-1 not only in tumoral models, but also in choroidal experimental neovascularization sharing similarities with human AMD. They identify therefore PAI-1 as a potential target for therapeutic ocular anti-angiogenic strategies.-Lambert, V., Munaut, C., Noël, A., Frankenne, F., Bajou, K., Gerard, R., Carmeliet, P., Defresne, M. P., Foidart, J.-M., Rakic, J.-M. Influence of plasminogen activator inhibitor type 1 on choroidal neovascularization. FASEB J. 15, 1021-1027 (2001)
\end{abstract}

Key Words: angiogenesis $\cdot$ retinal disease $\cdot$ proteases $\cdot$ viral vector $\cdot$ macular degeneration

Choroidal neovascularization Growing under the retina in severe forms of age-related macular degeneration (AMD) causes irreversible photoreceptors loss and the primary source of blindness in the Western world. Insight into the molecular mechanisms associated with subretinal neovascularization is important since current therapeutic modalities are limited and concern only a small percentage of affected individuals.

Molecular signals involved in the development of choroidal neovascularization are not well defined. Alpha-v integrins show a specific expression pattern during retinal angiogenesis (1) and antibodies to this integrin or its ligands such as vitronectin inhibit neovascularization in different retinal models (2-4). Among growth factors, several lines of evidence suggest that vascular endothelial growth factor (VEGF) could be implicated in the pathogenesis of AMD since this cytokine is present in pathological specimens $(5,6)$ and is expressed in several models of hypoxia-related retinal neovascularization (7). However, VEGF retinal overexpression alone was not able to induce choroidal neovascularization in a transgenic mouse model (8), suggesting either a retinal specificity in the mechanisms controlling angiogenesis or a requirement for additional angiogenic molecules in AMD. In the intact choroid, polarized secretion of VEGF by retinal pigment epithelium could play an important role in the maintenance of a normal choriocapillaris (9). Recent studies suggest also a role for Fas ligand in the control of choroidal neovascularization (10).

Angiogenesis is an invasive process that requires proteolysis of the extracellular matrix, proliferation, and migration of endothelial cells with simultaneous synthesis of new matrix components. Such migratory and tissue remodeling events are regulated by different proteolytic systems including matrix metalloproteases (MMPs) and serine proteases of the plasminogen/ plasminogen activator system. The specific roles of MMPs, plasminogen activators, and their inhibitors in neovascular chorioretinopathies remain largely unexplored. In retinal pathology, a mutation in a tissue inhibitor of MMPs (TIMP3) is associated with a rare form of macular dystrophy (11), and the expression of several MMPs has been demonstrated in human choroidal neovascular membranes (12). Urokinase-type (uPA) and tissue-type (tPA) plasminogen activators are serine proteases, both able to activate the zymogen plasminogen into plasmin. Plasmin is a broadly acting enzyme that degrades extracellular matrix proteins and activates pro-MMPs and growth factors (13). Plasmino-

\footnotetext{
${ }^{1}$ Correspondence: Laboratory of Tumor and Development Biology, University of Liège, Pathology Tower (B23), SartTilman, B-4000 Liège, Belgium. E-mail: vincent.lambert@ ulg.ac.be
} 
gen activator inhibitor type-1 (PAI-1) is the main physiological inhibitor of UPA and tPA. It not only regulates the proteolytic activity of uPA, but also determines the level of uPA bound to its cell surface receptor (UPAR) by promoting the rapid endocytosis of the trimolecular uPA-PAI-1-uPAR complex (14). The importance of PAI-1 for tumoral angiogenesis has recently been demonstrated in vivo in experimental squamous cell carcinomas (15). Elevated PAI-1 levels have been correlated clinically not only with a poor prognosis in patients suffering from a variety of cancers (16), but also with various chorioretinal pathologies $(17,18)$.

To evaluate the biological relevance of PAI-1 in subretinal angiogenesis, we induced choroidal neovascularization in vivo with argon laser burns (19) into PAI-1 ${ }^{-/-}$and wild-type (WT) mice. A choroidal neovascular membrane with leakage on fluorescein angiograms was produced at laser impacts in WT mice but not in PAI-1-deficient mice. In these PAI- $1^{-/-}$mice, choroidal neovascularization similar to that occurring in WT mice was restored when PAI-1 expression was achieved by injecting a recombinant adenoviral vector bearing PAI-1 cDNA. These observations highlight the proangiogenic activity of PAI-1 in choroidal neoangiogenesis and identify PAI-1 as a potential therapeutic target against AMD.

\section{MATERIALS AND METHODS}

\section{Genetically modified mice}

Animal experiments were performed in compliance with the Association for Research in Vision and Ophthalmology statement for the Use of Animals in Ophthalmic and Vision Research. Homozygous PAI-1-deficient mice $\left(\mathrm{PAI}-1^{-/-}\right)$and the corresponding WT mice $\left(\mathrm{PAI}^{+/+}\right)$of either sex, with a mixed genetic background of 87\% C57BL/6 and 13\% 129 strain, were used throughout this study (20). There were five or more mice in each group. The animals were maintained with a $12 \mathrm{~h}$ light/12 $\mathrm{h}$ dark cycle and had free access to food and water.

\section{Laser photocoagulation and fluorescein angiograms}

Choroidal neovascularization was induced in mice by laser burns as described previously (19). Briefly, mice were anesthetized with intraperitoneal (i.p.) injection of Avertin. Both pupils were dilated with $1 \%$ topical tropicamide; three burns were delivered (usually at the 9,12 , and 3 o'clock positions around the optic disc) using a green argon laser (532 nm; 50 $\mu \mathrm{m}$ diameter spot size; $0.05 \mathrm{~s}$ duration; $400 \mathrm{~mW}$ ) and a cover slide as a contact lens. Fluorescein angiograms were performed 14 days later by taking serial fundus photographs (Canon) after i.p. injection of $0.3 \mathrm{ml}$ of $1 \%$ fluorescein sodium (Ciba, Summit, N.J.). The percentage of burns developing late-phase hyperfluorescent spots (evaluated in comparison with the retinal normal vasculature) corresponding to the leakage of fluorescein from newly formed hyperpermeable vessels was evaluated. Animals were then killed, eyes were enucleated and either fixed in buffered 3.5\% formalin solution for routine histology or embedded in Tissue TeK (Miles Laboratories, Naperville, Ill.), and frozen in liquid nitrogen for cryostat sectioning.

\section{Quantitation of choroidal neovascularization}

A quantitative morphometric assessment of thickness of choroidal new vessels was carried out using a computer-assisted image analysis system (Olympus Micro Image version 3.0 for Windows 95/NT, Olympus Optical Co. Europe GmBH). Microscopic images (working magnification of $\times 200$ ) of hematoxylin-stained eye section were acquired via a video camera, digitalized, and analyzed. Frozen serial sections were cut throughout the entire extent of each burn and the thickest lesions (at least 5 sections per lesion) was used for the quantitation studies (96 sections studied). Neovascularization was estimated by the ratio $(B / C)$ of the thickness from the bottom of the pigmented choroidal layer to the top of the neovascular membrane (B) to the thickness of the intact pigmented choroid adjacent to the lesion $(\mathrm{C})$. The advantage of this method of quantification (over surface estimation) was its independence in relation to oblique sections (see example in Fig. 2c).

\section{Immunofluorescence}

Cryostat sections (5 $\mu \mathrm{m}$ in thickness) were fixed first in acetone at $-20^{\circ} \mathrm{C}$ and then in methanol at $4^{\circ} \mathrm{C}$ before incubation with the primary antibodies. Antibodies raised against mouse PECAM (rat monoclonal antibody; PharMingen, San Diego, Calif.; diluted 1/20) or mouse type IV collagen (guinea pig polyclonal antibody produced in our laboratory; diluted 1/100) were incubated for $1 \mathrm{~h}$ at room temperature. Antibodies to mouse PAI-1 (rabbit polyclonal antibody produced in our laboratory, $10 \mu \mathrm{g} / \mathrm{ml}$ ) were incubated overnight at $4^{\circ} \mathrm{C}$. The sections were washed three times for $10 \mathrm{~min}$ in phosphate buffered saline (PBS) before the appropriate secondary antibodies conjugated to fluoresceinisothiocyanate (FITC) or Texas red were added. Swine antirabbit (Dakopat, Glostrup, Denmark; diluted 1/40) or rabbit anti-rat (Sigma, St. Louis, Mo.; diluted 1/40) were applied for $30 \mathrm{~min}$. For double immunofluorescence-labeling studies, sections were first incubated with the two primary antibodies and then with FITC- and Texas red-conjugated secondary antibodies. After three washes in PBS for $10 \mathrm{~min}$ each and a final rinse in $10 \mathrm{mM}$ Tris-HCl buffer, $\mathrm{pH}$ 8.8, coverslips were mounted and labeling was analyzed under an inverted microscope equipped with epifluorescence optics. Staining for $\beta$-galactosidase activity was performed with 5 -bromo-4-chloro3 -indolyl- $\beta$-galactopyronoside (X-gal) as described (21). In some assays, primary anti-PAI-1 antibodies were preabsorbed for $15 \mathrm{~min}$ with recombinant PAI-1 ( $1 \mu \mathrm{g} / \mathrm{ml}$, a generous gift from P. Declerck, Katholieke Universiteit Leuven, Belgium).

\section{Adenovirus-mediated PAI-1 gene transfer}

Recombinant adenovirus bearing human PAI-1 (AdCMVPAI1), Escherichia coli $\beta$-galactosidase (AdCMVlacz) and control adenovirus (AdRR5) were generated as described (22). Twenty-four hours after laser spot production, mice were intravenously (i.v.) injected with $200 \mu \mathrm{l}$ of control or recombinant adenovirus $\left(7 \times 10^{8} \mathrm{PFU}\right)$. After 5 days, blood was sampled from the right retro-orbital sinus and PAI-1 antigen was measured by ELISA as reported (22). On day 14, mice were killed and eyes were excised and processed as described above. According to regulatory constraints, the virally infected animals were permanently housed under BL3 containment and, consequently, fluorescein angiograms could not be performed.

\section{RT-PCR for PAI-1 expression}

Total RNA from eyes were extracted using RNeasy Mini Kit (Qiagen, Chatsworth, Calif.) as described by the manufac- 

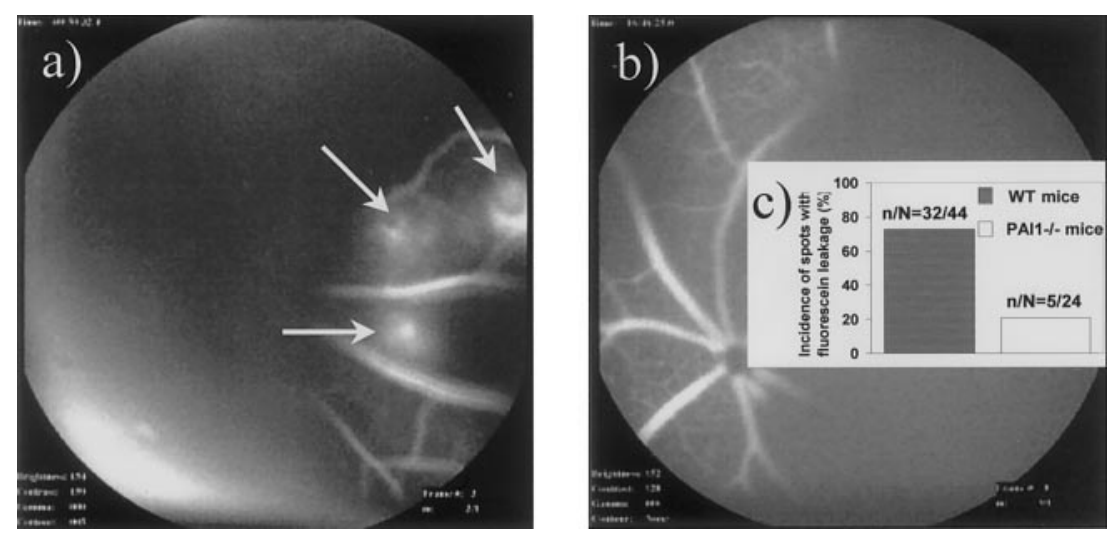

Figure 1. Fluorescein angiograms carried out 14 days after laser-induced rupture of Bruch's membrane. Fluorescein leakage (arrows) is observed from choroidal new vessels in WT $(a)$ but not in PAI-1 ${ }^{-/-}$mice showing only normal vasculature $(b)$. A threefold reduction in the percentage of leaking spots was obtained in PAI-1 ${ }^{-/-}$mice $(c) ; \mathrm{n} / \mathrm{N}=$ number of leaking spots/total number of laser burns $\left(X^{2}=16.8, P<0.0001\right)$.

turer. PAI-1 mRNA and 28S rRNA were measured in $10 \mathrm{ng}$ aliquots of total RNA using the GeneAmp Thermostable rTth reverse transcriptase RNA PCR kit (Perkin Elmer, Norwalk, Conn.) and two pairs of primers (Gibco BRL-Life Technologies, Grand Island, N.Y.): 5'-AGGGCTTCATGCCCCACTTCTTCA-3' (sense primer) and 5'-AGTAGAGGGGATTCACCAGCACCA-3' (antisense primer) for PAI-1 and 5'-GTTCACCCACTAATAGGGAACGTGA-3' (sense primer) and 5'-GGATTCTGACTTAGAGGCGTTCAGT-3' (antisense primer) for $28 \mathrm{~S}$. Reverse transcription was performed at $70^{\circ} \mathrm{C}$ for $15 \mathrm{~min}$, followed by $2 \mathrm{~min}$ incubation at $95^{\circ} \mathrm{C}$ for denaturation of RNA-DNA heteroduplexes. Amplification started by $15 \mathrm{~s}$ at $94^{\circ} \mathrm{C}, 20 \mathrm{~s}$ at $68^{\circ} \mathrm{C}$, and $10 \mathrm{~s}$ at $72^{\circ} \mathrm{C}(35$ cycles for PAI-1 and 19 cycles for 28S) and terminated by 2 min at $72^{\circ} \mathrm{C}$. RT-PCR products were resolved on $10 \%$ acrylamide gels and analyzed using a Fluor-S MultiImager (Bio-Rad, Hercules, Calif.) after staining with Gelstar (FMC BioProducts, Rockland, Maine) dye. The expected size is $191 \mathrm{bp}$ for PAI-1 and $212 \mathrm{bp}$ for $28 \mathrm{~S}$.

\section{Statistical analysis}

Data were analyzed with GraphPad Prism 3.0 (San Diego, Calif.). The $\chi^{2}$ test, Student's $t$ test, one-way ANOVA, and Newman-Keuls post tests were used to determine whether there were significant $(P<0.01)$ differences between WT and $\mathrm{PAI}^{-1}{ }^{-/-}$mice.

\section{RESULTS}

\section{Choroidal neovascularization in vivo in $\mathrm{PAI}-1^{-/-}$ and WT mice}

To determine whether the absence of PAI-1 influences choroidal neovascularization in vivo, we used a murine model of retinal photocoagulation with an argon laser. The photocoagulation induced trauma at the level of outer retina, retinal pigment epithelium, and Bruch's membrane, giving rise to choroidal neovascularization under the retina similar to that observed in AMD. The damage of the Bruch's membrane was immediately identified by the ophthalmoscopical appearance of a traumatic retinal bubble at the sites of laser burns. Fluorescein angiograms performed on day 14 (Fig. 1a, b) showed the appearance of newly formed microvessels with significant leakage of fluorescein in $72 \%$ $(32 / 44)$ of the laser-induced lesions. The incidence of leaking spots was reduced to $21 \%(5 / 24)$ in PAI- $1^{-/-}$ mice (Fig. $1 c, P<0.001$ ). Histological analysis and immunostaining with anti-PECAM and anti-collagen type IV antibodies confirmed the presence of newly formed capillaries in lesions identified by fluorescein angiography (Fig. 2). WT mice showed typically large "mushroom-like' areas of choroidal neovascularization at the site of laser-induced trauma, with migration of retinal pigmented epithelial cells along newly formed microvessels (Fig. 2a). The wound was usually not covered by a continuous layer of retinal pigmented epithelial cells. In PAI- $1^{-/-}$mice, the choroidal neovascular reaction was much more restricted and consisted of only a diffuse and moderate thickening covered by confluent retinal pigment epithelium (Fig. 2b). In most instances, these lesions were only indirectly identified by examination of the retinal photoreceptor damage. Immunostaining with anti-type IV collagen or antiPECAM antibodies failed to show any significant angiogenesis above the scarring tissue (Fig. $2 d$ ). Neovascularization was estimated by measuring, on serial sections, the maximal height of the lesion above the choroidal layer observed in neighboring intact zones. This was performed by determining the $\mathrm{B} / \mathrm{C}$ ratio between total thickness of lesions ('B' from the bottom of the choroid to the top of the neovascular area) to the thickness of adjacent normal choroid (' $\mathrm{C}$ '). A $45 \%$ reduction of the $\mathrm{B} / \mathrm{C}$ ratio was observed in PAI-deficient mice $(P<0.001)$ as compared to WT mice.

\section{PAI-1 is present in the neovascular area}

Immunohistochemical staining demonstrated the presence of PAI-1 exclusively within choroidal neovascular membrane, but not in normal intact zones of WT mice (Fig. 3a). Controls in which the primary antibody had been preabsorbed with recombinant PAI-1 were negative (Fig. 3b). No staining was observed at any location in PAI-1 ${ }^{-/-}$mice (Fig. $3 c$ ). RT-PCR applied on the eyes (Fig. $3 d$ ) demonstrated, 14 days after injection with adenoviral vector carrying AdCMVPAI1, a weak human PAI-1 mRNA expression in PAI-1-deficient mice. 
Figure 2. Histological analysis after laser treatment. Heamatoxylin-eosin staining of a representative large area of choroidal neovascularization at the site of laser-induced trauma in WT mice $(a)$ and more restricted reaction in PAI-1 ${ }^{-/-}$mice $(b)$. Immunofluorescence labeling of new vessels in WT $(c)$ or in PAI- $1^{-/-}$mice $(d)$ analyzed 14 days after laser photocoagulation. New vessels were detected with anti-mouse anti-collagen type IV antibody (red) and anti-mouse antiPECAM antibody (green). R: neural retina; Ch: choroid defined by yellow arrows which could contain normal large vessels not involved in the neo angiogenic process; $\mathrm{S}$ : sclera; B: total thickness from the choroid to the top of the neovascular area; $\mathrm{C}$ : thickness of the choroid-RPE (retinal pigmented epithelium) complex. B/C: ratio of the thickness from the choroid to the top of the neovascular area, to the thickness of the choroid-RPE complex measured on this section. White arrows localize the laser impact. Original magnification $200 \times$.
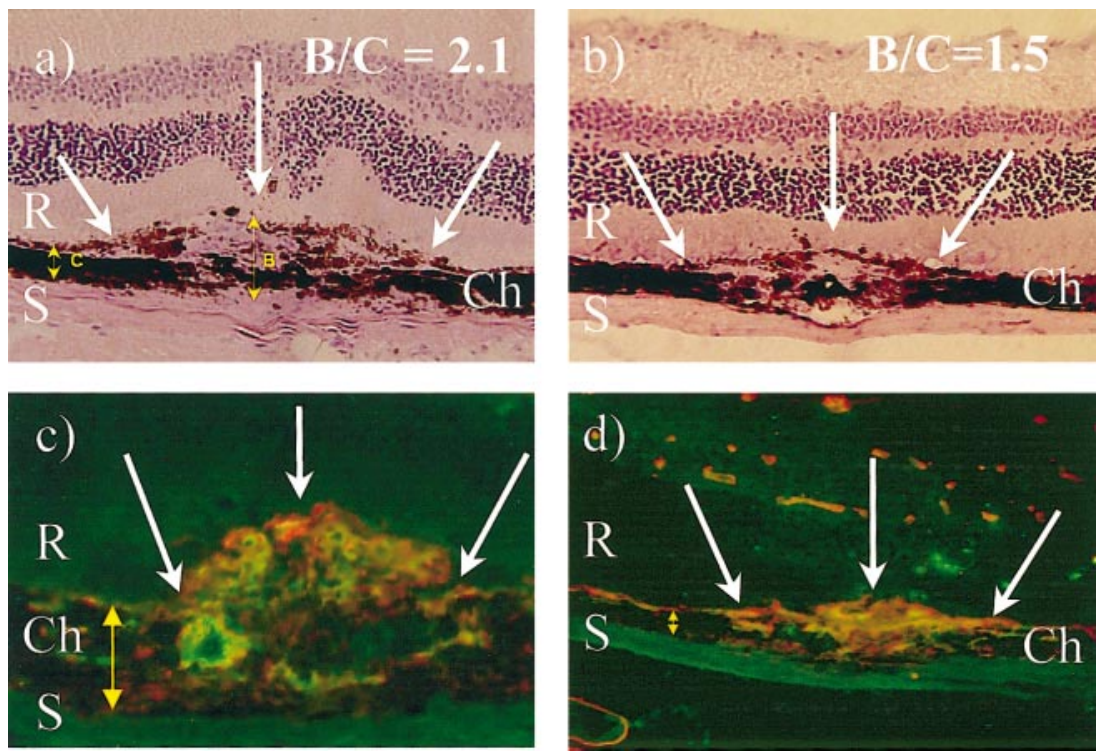

\section{PAI-1 adenovirus injection restores choroidal angiogenesis}

To further confirm the role of PAI-1 in choroidal angiogenesis in vivo, WT and $\mathrm{PAI}-1^{-/-}$mice were i.v. injected 1 day after laser burns with either a recombinant adenovirus (AdCMVPAI1) carrying human PAI-1 cDNA, a control virus (AdRR5), or a vector carrying LacZ cDNA (AdCMVLacZ). Immunostaining with anti-type IV collagen and anti-PECAM antibodies demonstrated a significant angiogenesis in PAI-1 ${ }^{-/-}$mice injected with AdCMVPAII (Fig. 4a) but not in PAI-1 ${ }^{-}{ }^{-}$mice injected with a control virus (Fig. $4 b$ ). The injection of the virus carrying the LacZ cDNA resulted in the expression of $\beta$-galactosidase in the retinal pigmented epithelium (Fig. 4c).
This demonstrates that the recombinant adenoviruses were able to transduce the PAI-1 cDNA into cells in close proximity to the burn. Four days after the injection of AdCMVPAI1, the measured plasma levels of human PAI-1 were higher in PAI-1 ${ }^{-/-}$mice (mean $7340 \mathrm{ng} / \mathrm{ml}$, range $1850-$ 12600 ) than the normal murine PAI-1 value in WT mice $(2 \mathrm{ng} / \mathrm{ml})$. PAI-1 was undetectable after $2 \mathrm{wk}$. Quantitation of the neovascularization on frozen sections (Fig. $4 d$ ) showed that the human gene expression in PAI-1-deficient mice resulted in a neovascular thickness ratio $(\mathrm{B} / \mathrm{C}) 90 \%$ of that observed in WT animals. In contrast, neovascularization estimated by the $\mathrm{B} / \mathrm{C}$ ratio in PAI-1-deficient mice injected with AdRR5 was similar to that observed in PAI-1-deficient animals.
Figure 3. Immunofluorescence labeling and RT-PCR for PAI-1. 14 days after laser treatment, PAI-1 was detected only in the neovascular area of WT mice $(a)$ and not in PAI-1deficient mice $(c)$. Immunostaining disappeared in WT animals when the primary antibody was preabsorbed with recombinant PAI-1 $(1 \mu \mathrm{g} / \mathrm{ml})(b)$. White arrows localize the laser burn sites. Original magnification $200 \times$. RT-PCR analysis $(d)$ identifying the PAI-1 mRNA expressed in the eyes of WT mice (lane 2) and of PAI-1-deficient mice injected with AdCMVPAI1 (lane 3). Lane 1 represents molecular weights, lane 4 eyes of $\mathrm{PAI}-/-$ mice and lane 5 negative control.
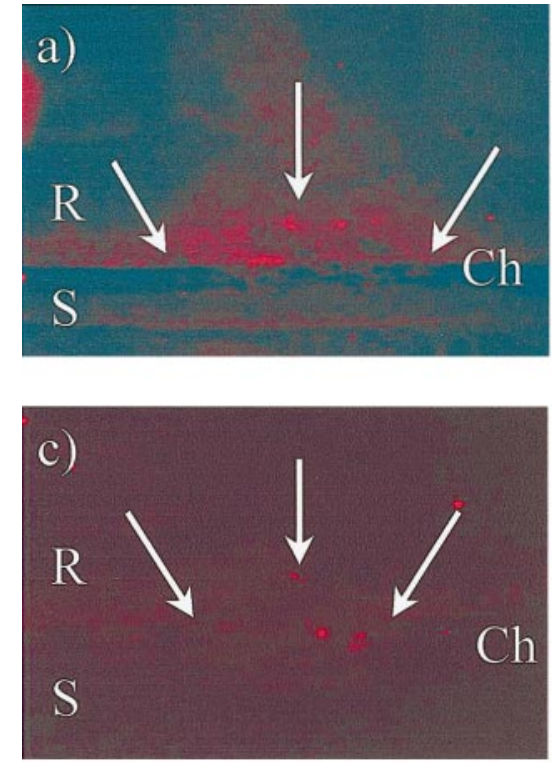

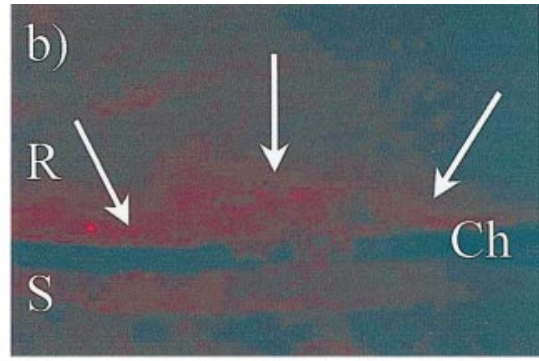

d)

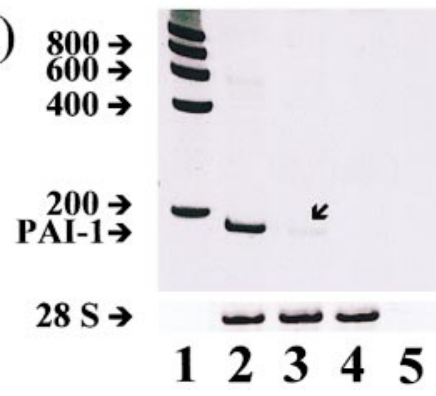



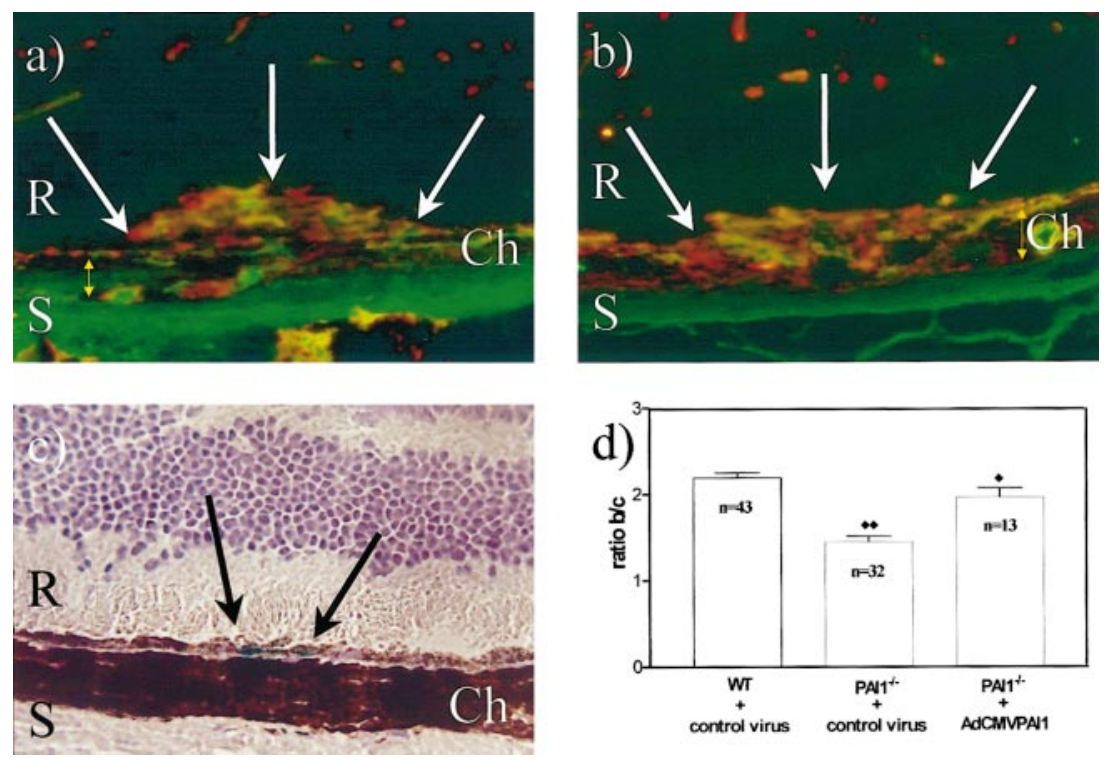

Figure 4. Injection of adenoviral vectors after laser photocoagulation. In $\mathrm{PAI}-1^{-/-}$ mice injected with adenovirus bearing human PAI-1 cDNA $(a)$, immunostaining of new vessels showed the same behavior as that found in WT mice injected with a control virus (not shown), whereas PAI$1^{-/-}$injected with a control virus failed to demonstrate significant neovascularization (b). LacZ expression (in blue) was detected in the retinal pigment epithelium (arrows) in mice injected with adenovirus bearing $\beta$-galactosidase cDNA $(c)$. Quantitation of the neovascularization by the $\mathrm{B} / \mathrm{C}$ ratio demonstrated a significant reduction in PAI$1-/-$ mice injected with a control virus $(t$ test, $P<0.001)$ while PAI- ${ }^{-/-}$mice injected with AdCMVPAI1 had a $\mathrm{B} / \mathrm{C}$ ratio ( $t$ test, $P=0.06)$ similar to that calculated in WT mice $(d) . n$ represents the number of different lesions analyzed. R: neural retina; Ch: choroid defined by yellow arrows that could contain normal large vessels not involved in the neo-angiogenic process; S: sclera.

\section{DISCUSSION}

Angiogenesis represents an invasive cellular process requiring the functional activity of a variety of molecules such as growth factors, extracellular matrix proteins, adhesion receptors, and proteolytic enzymes (23). MMPs and serine proteases have been implicated in the extracellular matrix remodeling associated with neo-angiogenesis. Since most MMPs are secreted as zymogens, their activation requires a limited proteolysis by plasmin. Neovascularization requires therefore a delicate balance between the activation of the serine and metalloproteases and their inhibition by specific inhibitors. The specific roles of MMPs, plasminogen activators, and inhibitors in neovascular chorioretinopathies remain largely unexplored.

Previous clinical studies detected measurable concentrations of tPA and PAI in the aqueous humor of normal eyes $(24,25)$. An increase in Bruch's membrane TIMP-3 (26) and interphotoreceptor matrix MMP-2 (27) has been associated with age-related macular degeneration. In the vitreous fluid of diabetic patients suffering from proliferative retinopathy, elevated concentrations of ProMMP-9 (28), tPA, and PAI-1 (29) were recently reported to be associated with high VEGF levels. As PAI-1 and TIMP-3 inhibit MMPs activation, it might have been anticipated that they reduce choroidal angiogenesis. The apparent paradox of increased tissue levels of PAI and TIMP-3 in choroidal pathology associated with neovascularization suggests that their contribution to the angiogenic ocular disorders could be different from that anticipated. We reported recently that PAI-1 is a key proangiogenic molecule during tumorigenesis and that PAI-1 deletion results in the absence of tumor formation in an animal model of squamous cells carcinoma (15).

We demonstrate here that PAI-1 plays an important role in choroidal neovascularization. In a model of laser-induced choroidal neovascularization, angiogenesis detected by fluorescein angiography and neovascular volume appreciated by immunohistochemistry and quantitative histology were reduced in PAI-1-deficient animals. Furthermore, restoration of PAI-1 expression in these mice by injection with recombinant adenoviruses bearing human PAI-1 cDNA led to a choroidal neovascularization identical to that observed in WT animals. It could be argued that the inflammatory reaction may play a role in the results involving adenoviral delivery. This is unlikely, as control and lacZ viruses were inefficient. Quantification of inflammatory cells in the lesions failed to demonstrate any significant difference (data not shown).

Although it has been suggested in a model of retinopathy of prematurity that up-regulation of endogenous PAI-1 could protect from retinal and choroidal neovascularization (30), in accordance with clinical observations our results suggest, paradoxically, the opposite effect and show that PAI-1 expression is necessary for choroidal angiogenesis.

Taken together with results observed previously in tumoral models, our observations confirm the role of PAI-1 in the development of pathological angiogenesis. The effect of PAI-1 is indeed restricted to tumoral and ocular pathological neovascularization but is not observed in placentation, embryo-development, and wound-healing reaction (T. Frandsen, unpublished observations), which are essentially normal in PAI-1-deficient mice.

Although the exact mechanism of action of PAI-1 remains to be elucidated, at least three different hypothesis can be formulated. PAI-1 could prevent excessive matrix degradation against uPA-mediated degradation, thereby providing a cell adhesion substrate for endothelial cell migration. It has been shown in vitro that excessive proteolysis prevents the coordinated assembly of endothelial cells into capillary shoots (31). 
PAI-1 could also be considered as the molecular switch that governs UPAR- and/or integrin-mediated cell adhesion and release (32). Finally, through the inhibition of plasmin, uPA, and tPA, PAI-1 could promote angiogenesis by reducing the angiostatin generation from plasminogen (33). The use of adenovirus with mutated PAI-1 forms modulating these different pathways is one of the strategies that could give new insight into the mechanisms of PAI-1 action in angiogenesis.

Laser-induced choroidal neovascularization in mice is useful for basic investigation of choroidal angiogenesis, although it probably differs from that occurring naturally in human AMD. Our observations nevertheless emphasize the essential role of PAI-1 in the development of subretinal neovascularization and identify PAI-1 as a potential target for therapeutic retinal antiangiogenic strategies.

We thank F. Olivier and C. Stegen for their collaboration and P. Gavitelli for technical assistance. This study was supported by grants from Les Amis des Aveugles, Ghlin, the Fondation Léon Frédéricq, University of Liège, the Fonds d'Investissements de Recherche Scientifique, CHU, Liège, the CGER-Assurances, Belgium. A.N. is a senior research associate from the National Fund for Scientific Research (FNRS), Belgium, and K.B. is the recipient of a grant from FNRS-Televie. The work made in the BL3 was partially supported by the Anti-Cancer Research Fund from the University of Liège, Belgium.

\section{REFERENGES}

1. Brooks, P. C., Clark, R. A., and Cheresh, D. A. (1994) Requirement of vascular integrin alpha v beta 3 for angiogenesis. Science 264, 569-571

2. Friedlander, M., Theesfeld, C. L., Sugita, M., Fruttiger, M., Thomas, M. A., Chang, S., and Cheresh, D. A. (1996) Involvement of integrins alpha v beta 3 and alpha v beta 5 in ocular neovascular diseases. Proc. Natl. Acad. Sci. USA 93, 9764-9769

3. Luna, J., Tobe, T., Mousa, S. A., Reilly, T. M., and Campochiaro, P. A. (1996) Antagonists of integrin alpha v beta 3 inhibit retinal neovascularization in a murine model. Lab. Invest. 75, 563-573

4. Hammes, H. P., Brownlee, M., Jonczyk, A., Sutter, A., and Preissner, K. T. (1996) Subcutaneous injection of a cyclic peptide antagonist of vitronectin receptor-type integrins inhibits retinal neovascularization. Nat. Med. 2, 529-533

5. Kvanta, A., Algvere, P. V., Berglin, L., and Seregard, S. (1996) Subfoveal fibrovascular membranes in age-related macular degeneration express vascular endothelial growth factor. Invest. Ophthalmol. Vis. Sci. 37, 1929-1934

6. Aiello, L. P., Avery, R. L., Arrigg, P. G., Keyt, B. A., Jampel, H. D., Shah, S. T., Pasquale, L. R., Thieme, H., Iwamoto, M. A., and Park, J. E. (1994) Vascular endothelial growth factor in ocular fluid of patients with diabetic retinopathy and other retinal disorders. N. Engl. J. Med. 331, 1480-1487

7. Pierce, E. A., Avery, R. L., Foley, E. D., Aiello, L. P., and Smith, L. E. (1995) Vascular endothelial growth factor/vascular permeability factor expression in a mouse model of retinal neovascularization. Proc. Natl. Acad. Sci. USA 92, 905-909

8. Okamoto, N., Tobe, T., Hackett, S. F., Ozaki, H., Vinores, M. A., LaRochelle, W., Zack, D. J., and Campochiaro, P. A. (1997) Transgenic mice with increased expression of vascular endothelial growth factor in the retina: a new model of intraretinal and subretinal neovascularization. Am. J. Pathol. 151, 281-291

9. Blaauwgeers, H. G., Holtkamp, G. M., Rutten, H., Witmer, A. N., Koolwijk, P., Partanen, T. A., Alitalo, K., Kroon, M. E., Kijlstra, A., van Hinsbergh, V. W., et al. (1999) Polarized vascular endothelial growth factor secretion by human retinal pigment epithelium and localization of vascular endothelial growth factor receptors on the inner choriocapillaris. Evidence for a trophic paracrine relation. Am. J. Pathol. 155, 421-428

10. Kaplan, H. J., Leibole, M. A., Tezel, T., and Ferguson, T. A. (1999) Fas ligand (CD95 ligand) controls angiogenesis beneath the retina. Nat. Med. 5, 292-297

11. Weber, B. H., Vogt, G., Pruett, R. C., Stohr, H., and Felbor, U. (1994) Mutations in the tissue inhibitor of metalloproteinases-3 (TIMP3) in patients with Sorsby's fundus dystrophy. Nat. Genet. 8, 352-356

12. Steen, B., Sejersen, S., Berglin, L., Seregard, S., and Kvanta, A. (1998) Matrix metalloproteinases and metalloproteinase inhibitors in choroidal neovascular membranes. Invest. Ophthalmol. Vis. Sci. 39, 2194-2200

13. Andreasen, P. A., Kjoller, L., Christensen, L., and Duffy, M. J. (1997) The urokinase-type plasminogen activator system in cancer metastasis: a review. Int. J. Cancer 72, 1-22

14. Blasi, F. (1999) Proteolysis, cell adhesion, chemotaxis, and invasiveness are regulated by the u-PA-u-PAR-PAI-1 system. Thromb. Haemost. 82, 298-304

15. Bajou, K., Noel, A., Gerard, R. D., Masson, V., Brunner, N., Holst-Hansen, C., Skobe, M., Fusenig, N. E., Carmeliet, P., Collen, D., et al. (1998) Absence of host plasminogen activator inhibitor 1 prevents cancer invasion and vascularization. Nat. Med. 4, 923-928

16. Pedersen, H., Brunner, N., Francis, D., Osterlind, K., Ronne, E., Hansen, H. H., Dano, K., and Grondahl-Hansen, J. (1994) Prognostic impact of urokinase, urokinase receptor, and type 1 plasminogen activator inhibitor in squamous and large cell lung cancer tissue. Cancer Res. 54, 4671-4675

17. Grant, M. B., Ellis, E. A., Caballero, S., and Mames, R. N. (1996) Plasminogen activator inhibitor-1 overexpression in nonproliferative diabetic retinopathy. Exp. Eye Res. 63, 233-244

18. Iijima, H., Iida, T., Murayama, K., Imai, M., and Gohdo, T. (1999) Plasminogen activator inhibitor 1 in central serous chorioretinopathy. Am. J. Ophthalmol. 127, 477-478

19. Tobe, T., Ortega, S., Luna, J. D., Ozaki, H., Okamoto, N., Derevjanik, N. L., Vinores, S. A., Basilico, C., and Campochiaro, P. A. (1998) Targeted disruption of the FGF2 gene does not prevent choroidal neovascularization in a murine model. Am. J. Pathol. 153, 1641-1646

20. Carmeliet, P., Kieckens, L., Schoonjans, L., Ream, B., van Nuffelen, A., Prendergast, G., Cole, M., Bronson, R., Collen, D., and Mulligan, R. C. (1993) Plasminogen activator inhibitor-1 gene-deficient mice. I. Generation by homologous recombination and characterization. J. Clin. Invest. 92, 2746-2755

21. Behringer, R. R., Crotty, D. A., Tennyson, V. M., Brinster, R. L., Palmiter, R. D., and Wolgemuth, D. J. (1993) Sequences 5' of the homeobox of the Hox-1.4 gene direct tissue-specific expression of lacZ during mouse development. Development 117, 823833

22. Carmeliet, P., Moons, L., Lijnen, R., Janssens, S., Lupu, F., Collen, D., and Gerard, R. D. (1997) Inhibitory role of plasminogen activator inhibitor-1 in arterial wound healing and neointima formation: a gene targeting and gene transfer study in mice. Circulation 96, 3180-3191

23. Folkman, J., and D'Amore, P. A. (1996) Blood vessel formation: what is its molecular basis? Cell 87, 1153-1155

24. Smalley, D. M., Fitzgerald, J. E., Taylor, D. M., Cone, R. E., and O'Rourke, J. (1994) Tissue plasminogen activator activity in human aqueous humor. Invest. Ophthalmol. Vis. Sci. 35, 48-53

25. Steinkamp, G. W., Hattenbach, L. O., Heider, H. W., and Scharrer, I. (1993) Plasminogen activator and PAI. Detection in aqueous humor of the human eye. Ophthalmologie 90, 73-75

26. Kamei, M., and Hollyfield, J. G. (1999) TIMP-3 in Bruch's membrane: changes during aging and in age-related macular degeneration. Invest. Ophthalmol. Vis. Sci. 40, 2367-2375

27. Plantner, J. J., Jiang, C., and Smine, A. (1998) Increase in interphotoreceptor matrix gelatinase A (MMP-2) associated with age-related macular degeneration. Exp. Eye Res. 67, 637645

28. Kosano, H., Okano, T., Katsura, Y., Noritake, M., Kado, S., Matsuoka, T., and Nishigori, H. (1999) ProMMP-9 (92 kDa gelatinase) in vitreous fluid of patients with proliferative diabetic retinopathy. Life Sci. 64, 2307-2315

29. Hattenbach, L. O., Allers, A., Gumbel, H. O., Scharrer, I., and Koch, F. H. (1999) Vitreous concentrations of TPA 
and plasminogen activator inhibitor are associated with VEGF in proliferative diabetic vitreoretinopathy. Retina 19, 383-389

30. Bullard, L. E., Rajaratnam, V. S., and Collier, R. J. (1999) Evidence that AL-3789 inhibits retinal neovascularization in an animal model of ROP by inducing retinal PAI-1. Invest. Ophthalmol. Vis. Sci. 40, 3255 (Abstr.)

31. Montesano, R., Pepper, M. S., Mohle-Steinlein, U., Risau, W., Wagner, E. F., and Orci, L. (1990) Increased proteolytic activity is responsible for the aberrant morphogenetic behavior of endothelial cells expressing the middle T oncogene. Cell 62, $435-445$
32. Noel, A., Bajou, K., Masson, V., Devy, L., Frankenne, F., Rakic, J. M., Lambert, V., Carmeliet, P., and Foidart, J. M. (1999) Regulation of cancer invasion and vascularization by plasminogen activator inhibitor-1. Fibrinolysis Proteolysis 13, 220-225

33. Gately, S., Twardowski, P., Stack, M. S., Cundiff, D. L., Grella, D., Castellino, F. J., Enghild, J., Kwaan, H. C., Lee, F., Kramer, R. A., et al. (1997) The mechanism of cancer-mediated conversion of plasminogen to the angiogenesis inhibitor angiostatin. Proc. Natl. Acad. Sci. USA 94, 10868-10872

Received for publication June 22, 2000. Revised for publication September 21, 2000. 